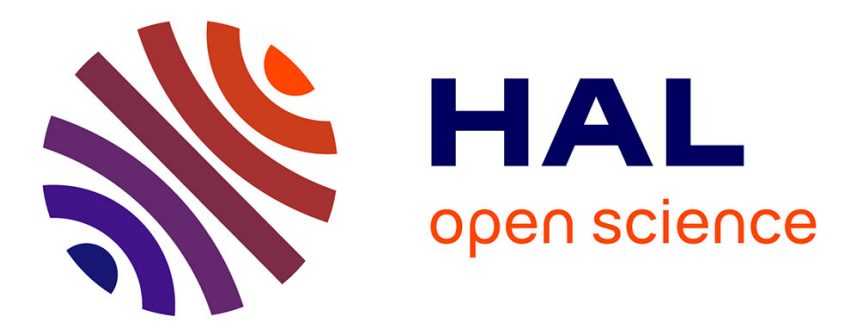

\title{
Development of TiN-Si3N4 Nano Composite Coatings for Wear Resistance Applications
}

\author{
A. Dias, J. van Breda, P. Moretto, J. Ordelman
}

\section{To cite this version:}

A. Dias, J. van Breda, P. Moretto, J. Ordelman. Development of TiN-Si3N4 Nano Composite Coatings for Wear Resistance Applications. Journal de Physique IV Proceedings, 1995, 05 (C5), pp.C5-831-C5840. 10.1051/jphyscol:1995599 . jpa-00253963

\section{HAL Id: jpa-00253963 https://hal.science/jpa-00253963}

Submitted on 1 Jan 1995

HAL is a multi-disciplinary open access archive for the deposit and dissemination of scientific research documents, whether they are published or not. The documents may come from teaching and research institutions in France or abroad, or from public or private research centers.
L'archive ouverte pluridisciplinaire HAL, est destinée au dépôt et à la diffusion de documents scientifiques de niveau recherche, publiés ou non, émanant des établissements d'enseignement et de recherche français ou étrangers, des laboratoires publics ou privés. 


\title{
Development of $\mathrm{TiN}_{-} \mathrm{Si}_{3} \mathrm{~N}_{4}$ Nano Composite Coatings for Wear Resistance Applications
}

\author{
A.G. Dias, J.H. van Breda*, P. Moretto and J. Ordelman* \\ Commission of the European Communities, Joint Research Centre, Institute for Advanced Materials, \\ P.O. Box 2, 1755 ZG Petten, The Netherlands \\ * Netherlands Energy Research Foundation (ECN), Energy Engineering Division, P.O. Box 1, \\ 1755 ZG Petten, The Netherlands
}

\begin{abstract}
The engineering of conventional TiN coatings to attain hardness of the order of ultrahard coatings (e.g. c-BN) by a controlled incorporation of silicon atoms in the titanium nitride lattice leading to the formation of a TiN$\mathrm{Si}_{3} \mathrm{~N}_{4}$ composite material is discussed. An a-priori thermodynamic approach complemented by thermochemical equilibrium calculations was used to evaluate convenient precursors and processing parameters for the production of this novel coating material. The multiphase nature of preliminary test samples deposited by PACVD is confirmed by X-ray diffraction. IR spectroscopy and EPMA analysis. The films are made up of TiN nanocrystallites embedded in an amorphous $\mathrm{Si}_{3} \mathrm{~N}_{4}$ tissue with small amounts of free $\mathrm{Si}$, as predicted by previous Ti-Si-N phase diagram calculations.
\end{abstract}

\section{INTRODUCTION}

The efficiency of tribological coatings providing substantial economic benefits by improving the wear resistance of steel cutting, drilling and metal forming tools is well established. The hardness of the coating material is of primary importance in the great majority of these wear applications.

Consequently a great variety of hard coatings have entered the tools market in the past decades, increasing the hardness of the cemented carbide steels ( $1900 \mathrm{HV}$ ) formerly used by the tools industry to values up to $3200 \mathrm{HV}$ (Silicon Carbide coatings). The success of coated wear parts has triggered the search for new types of coatings with still higher wear resistance. The starting point for the development of the so-called ultrahard coatings, i. e. coating materials with hardness in excess of $4000 \mathrm{HV}$, was the hardest known bulk materials, Diamond and cubic Boron Nitride (c-BN). Diamond and c-BN are metastable materials which present specific problems of control of the deposition process for the synthesis of these particular hard crystallographic phases; indeed, despite intensive efforts being undertaken worldwide to develop commercially viable deposition processes, the actual industrial production of tribological Diamond and c-BN coatings is still rather limited.

A new strategy for the development of high wear resistant coatings based on the knowledge of how materials composition and structure influence the properties and performances of the coating has recently emerged [1]. This novel approach is applied in this. work to develop a new generation of ultrahard coatings by modifying conventional coating materials such as Titanium Nitride (TiN).

\section{WEAR RESISTANT MATERIALS}

\subsection{Wear resistance and chemical bonding}

The materials currently used as hard and wear protective layers are characterized by a great variety of compositions with different chemical bonding and structure. Materials which exhibit high intrinsic hardness generally have high cohesive energy, short bond length and a high degree of covalent bonding 
[2]. The hardest metallic and covalent materials contain the following chemical elements: B, C, N, Si and Ti [3]. The relative degree of hardness of the most important stoichiometric coating materials can be easily visualized in the hardness pyramid of Fig. 1.

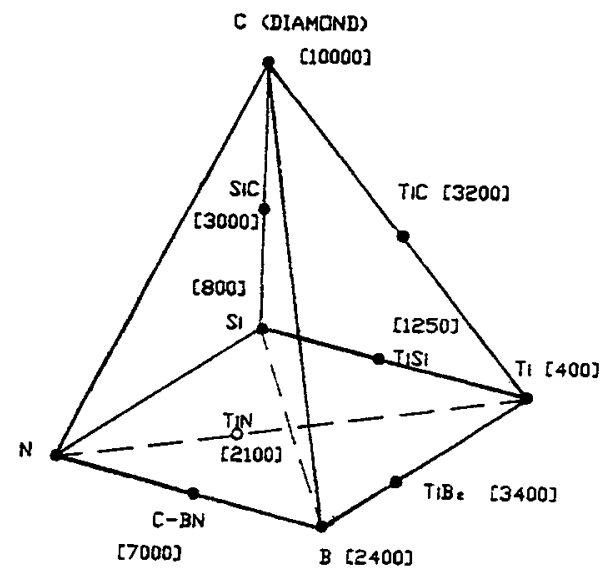

Figure 1 : "Hardness" pyramid C-B-N-Si-Ti.

The intrinsic hardness of a material is expected to increase proportionally to the degree of covalent bonding. Diamond, which is the hardest material known, has purely covalent bonds, while c-BN, the second hardest material, although being predominantly covalent bonded has a small ionic contribution. Another example of this behaviour is the difference in hardness between Titanjum Oxide (TiO) and TiN, which have the same crystallographic structure $(\mathrm{B} 1-\mathrm{NaCl})$ and similar lattice parameters, but an increasing degree of covalent bonding when Oxygen is replaced by Nitrogen [1].

In this framework, silicon is an ideal candidate to be used in the tailoring of conventional TiN coatings. By introducing a covalent bond former such as $\mathrm{Si}$, the $\mathrm{Ti}-\mathrm{Si}-\mathrm{N}$ coating system is driven into the direction of covalent hard materials. An increase in hardness is expected for this composite coating, as predicted by Fig. 1 .

\subsection{Wear resistance and microstructure}

Not only the nature of interatomic forces is important determining the actual wear resistance of the coating but also its micro-structure. The wear resistance of a coating is related to its intrinsic hardness as well as to the ability of the material to accommodate internal stresses resulting from the pressure of the cutting tool against the workpiece. A multiphase coating with a higher amount of low energy interfaces will provide the energy dissipation mechanisms necessary to reduce these stresses.

Substantial "hardness" enhancement has been reported for nano-composite materials with metallic agglomerates with diameters of a few nanometres embedded in a ceramic matrix. This apparent hardness increase was interpreted as being due to a change in the deformation mechanism occurring in the transition from isolated metallic particles to an inter connective tissue, which became able to accommodate most of the deformation [4].

Also in this respect the Ti-Si-N coating system seems to be very promising. In the Ti-Si-N phase diagram of Fig. 2 [5] an equilibrium phase composition involving a metallic TiN phase and an insulating silicon nitride $\left(\mathrm{Si}_{3} \mathrm{~N}_{4}\right)$ phase stabilized by free silicon atoms is attained in the temperature range $700-1000^{\circ} \mathrm{C}$, i.e. the formation of a TiN-Si $\mathrm{N}_{4}$ composite material is predicted.

The only detrimental feature of $\mathrm{Si}$ addition to TiN could be a reduction of the coating-substrate adhesion as a result of the lower tendency of highly directional covalent bonds to chemically interact with other materials. Specific pre-deposition treatments of the substrate [6] and/or deposition of adequate intermediate layers $[7,8]$, such as Ti/TiN/TiSiN, could be envisaged to overcome this problem. 


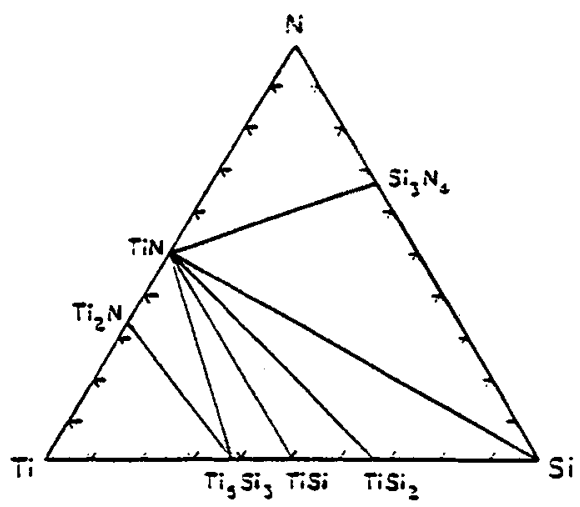

Figure 2 : Ti-Si-N phase diagram (temperature range $700^{\circ}-1000^{\circ} \mathrm{C}$ ).

\section{PROCESS ROUTES FOR THE PRODUCTION OF TIN-Si ${ }_{3} \mathrm{~N}_{4}$ COMPOSITE COATINGS}

The bibliography $[9,10]$ on the production of $\mathrm{TiN}_{-} \mathrm{Si}_{3} \mathrm{~N}_{4}$ composite coatings by Physical Vapour Deposition (PVD) methods is of limited interest for wear applications.

Chemical Vapour Deposition (CVD) Ti-Si-N films were produced by Hirai and co-workers [11, 12, 13, 14] at temperatures between 1050 and $1450^{\circ} \mathrm{C}$ using $\mathrm{TiCl}_{4} / \mathrm{SiCl}_{4} / \mathrm{NH}_{3} / \mathrm{H}_{2}$ gas mixtures. The films had also a composite nature, consisting of granular TiN dispersions embedded in an amorphous (for deposition temperatures below $1200^{\circ} \mathrm{C}$ ) or crystalline $\mathrm{Si}_{3} \mathrm{~N}_{4}$ matrix. The observed phase composition is also predicted by the phase diagram of Fig. 2 .

More recently Shizhi et al. [15] obtained Ti-Si-N coatings from $\mathrm{TiCl}_{4} / \mathrm{SiCl}_{4} / \mathrm{N}_{2} / \mathrm{H}_{2}$ gas mixtures at $560^{\circ}$ $\mathrm{C}$ by Plasma Assisted CVD (PACVD). These coatings were also multiphase, containing crystalline TiN, amorphous $\mathrm{Si}_{3} \mathrm{~N}_{4}$ and a small amount of free silicon. Coatings containing 10-15 atom \% of total silicon showed 3 times higher microhardness values than the best CVD TiN coatings. In the most recent report [16] on the production of $\mathrm{TiN}-\mathrm{Si}_{3} \mathrm{~N}_{4}$ composite coatings, produced by PACVD in an Ar diluted $\mathrm{TiCl}_{4} / \mathrm{SiCl}_{4} / \mathrm{N}_{2} / \mathrm{H}_{2}$ gaseous mixture at temperatures between $500^{\circ} \mathrm{C}$ and $700^{\circ} \mathrm{C}$ using a pulsed dc discharge, micro hardness values in excess of conventional TiN coatings were also attained for coatings with a silicon content of 10-15\%. No evidence for the presence of titanium silicides or free silicon atoms was found in these coatings.

From these results is clear that CVD and in particular PACVD are the most promising processing techniques to produce $\mathrm{TiN}-\mathrm{Si}_{3} \mathrm{~N}_{4}$ composite coatings with high microhardness values. The major advantage of plasma assisted CVD over conventional thermally assisted CVD processes is the reduction of processing temperature. The ability of plasma deposition processes to influence the microstructure of the coating by controlling the energetic particle bombardment of the substrate $[17,18]$ is another important driving force towards PACVD coatings processing since microstructural features, like density, grain size and orientation determine essentially the wear behaviour of caatings. Therefore, our final goal is the production of PACVD TiN-Si $\mathrm{N}_{4}$ composite coatings for high wear resistance applications.

\section{PRODUCTION OF TIN-Si $\mathbf{N}_{4}$ COMPOSITE COATINGS}

\subsection{Precursor selection}

The first step towards the production of $\mathrm{TiN}-\mathrm{Si}_{3} \mathrm{~N}_{4}$ composite coating materials by CVD and/or PACVD is the selection the most adequate silicon, nitrogen and titanium precursors.

Although $\mathrm{SiCl}_{4}$ has been used in previous work as $\mathrm{Si}$ precursor, we think that $\mathrm{SiH}_{4}$ could be a rather more convenient precursor. In fact $\mathrm{SiH}_{4}$, having a positive Gibbs free energy of formation $\left(\Delta \mathrm{G}_{\mathrm{npt}}^{\circ}=13.184\right.$ $\mathrm{kcal} / \mathrm{mole})$ compared to $\mathrm{SiCl}_{4}$ which is highly negative $\left(\Delta \mathrm{G}^{\circ}{ }_{\mathrm{npt}}=-148.856 \mathrm{kcal} / \mathrm{mole}\right)$, would be easily dissociated when participating in reactions at lower temperatures. 
As for $\mathrm{Ti}$ precursor, $\mathrm{TiCl}_{4}$ is currently used, whereas for nitrogen, $\mathrm{N}_{2}\left(\mathrm{H}_{2}\right.$ being in this case necessary to reduce $\mathrm{TiCl}_{4}$ vapours) or $\mathrm{NH}_{3}$, eventually diluted in $\mathrm{H}_{2}$ and/or $\mathrm{N}_{2}$, are possible alternatives. Due to the possibility of low temperature gas phase reactions with $\mathrm{TiCl}_{4}$ leading to powder formation $[19,20], \mathrm{NH}_{3}$ will not be considered further in this study.

\subsection{Preliminary feasibility study}

The adequacy of different gaseous mixtures and the corresponding range of processing temperatures can be easily accessed using a simplified approach combining the dependence on temperature of the Gibbs free energy of the two reactions leading to the formation of $\mathrm{TiN}$ and $\mathrm{Si}_{3} \mathbf{N}_{4}$.

In the case of $\mathrm{TiCl}_{4} / \mathrm{SiH}_{4} / \mathrm{N}_{2} / \mathrm{H}_{2}$ gas mixtures where $\mathrm{N}_{2}$ is used as nitrogen precursor the reaction is:

$$
\begin{gathered}
2 \mathrm{TiCl}_{4}+4 \mathrm{H}_{2}+\mathrm{N}_{2}=2 \mathrm{TiN}+8 \mathrm{HCl} \\
3 \mathrm{SiH}_{4}+2 \mathrm{~N}_{2} \stackrel{\mathrm{H}_{2}}{=} \mathrm{Si}_{3} \mathrm{~N}_{4}+6 \mathrm{H}_{2}
\end{gathered}
$$

The dependence of the Gibbs free energy of the two reactions on temperature is shown in Fig. 3. The dependence of the Gibbs free energy of the reaction:

$$
3 \mathrm{SiCl}_{4}+2 \mathrm{~N}_{2}+6 \mathrm{H}_{2}=\mathrm{Si}_{3} \mathrm{~N}_{4}+12 \mathrm{HCl}
$$

where $\mathrm{SiCl}_{4}$ is used as $\mathrm{Si}$ precursor instead of $\mathrm{SiH}_{4}$, is also shown in Fig. 3.

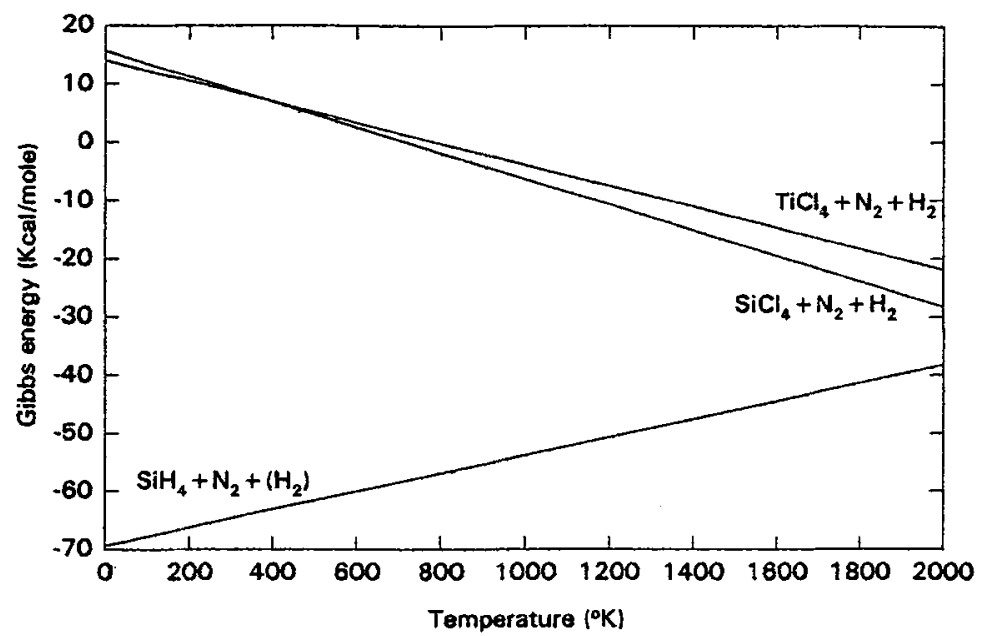

Figure 3 : Temperature dependence of the Gibbs free energy of formation of TiN from reaction (1) and $\mathrm{Si}_{3} \mathrm{~N}_{4}$ from reactions (2) and (3), respectively.

Both reactions describing the production of $\mathrm{Si}_{3} \mathrm{~N}_{4}$ have a negative Gibbs free energy. Reaction 2 has however a more negative Gibbs free energy in the whole temperature range of interest, favouring the utilization of $\mathrm{SiH}_{4}$ as silicon precursor instead of $\mathrm{SiCl}_{4}$, as can be seen in Fig. 3 .

The production of $\mathrm{Si}_{3} \mathrm{~N}_{4}$ via equation 2 is not influenced by $\mathrm{H}_{2}$ dilution, since this gas is already a product of the reaction. This reaction is not favoured by increasing deposition temperatures due to its positive temperature coefficient.

The production of TiN only becomes thermodynamically favourable at temperatures above $750^{\circ} \mathrm{C}$. The deposition temperatures required for the $\mathrm{CVD}$ of $\mathrm{TiN}-\mathrm{Si}_{3} \mathrm{~N}_{4}$ composite coatings from 
$\mathrm{TiCl}_{4} / \mathrm{SiH}_{4} / \mathrm{N}_{2} / \mathrm{H}_{2}$ gas mixtures should be as low as possible to benefit the deposition of $\mathrm{Si}_{3} \mathrm{~N}_{4}$, at the same time enabling the deposition of the TiN phase.

These results have shown that the deposition of $\mathrm{TiN}-\mathrm{Si}_{3} \mathrm{~N}_{4}$ nano composite coatings is favoured by using $\mathrm{TiCl}_{4} / \mathrm{SiH}_{4} / \mathrm{N}_{2} / \mathrm{H}_{2}$ instead of $\mathrm{TiCl}_{4} / \mathrm{SiCl}_{4} / \mathrm{N}_{2} / \mathrm{H}_{2}$ gas mixtures.

\subsection{Thermochemical equilibrium calculations}

A second level of approach to the deposition of $\mathrm{TiN}-\mathrm{Si}_{3} \mathrm{~N}_{4}$ composite coatings consists in calculating the composition which results in a minimum of the total Gibbs free energy of the $\mathrm{TiCl}_{4} / \mathrm{SiH}_{4} / \mathrm{N}_{2} / \mathrm{H}_{2}$ chemical system under given conditions of temperature, total pressure and reactive gas concentrations.

These thermochemical calculations assume that the chemical system is in thermodynamic equilibrium and the reactor is a closed system. These conditions are not entirely respected in CVD systems, where gas flow rate and kinetic effects play an important role, and are hardly meet in PACVD systems where, apart from that, the chemical system is far from thermodynamic equilibrium. Nevertheless, this approach is quite useful to get further insights into the sensitivity of the reactive system to modifications of experimental parameters (temperature, pressure etc.), allowing to reduce the number of experiments required for the optimization of the deposition process. The calculations were performed with the ChemSage [21] software package. The list of chemical species considered in this calculations are listed in Table I. The set of titanium silicides ( $\mathrm{TiSi}, \mathrm{Ti}_{2} \mathrm{Si}, \mathrm{Ti}_{3} \mathrm{Si}_{2} \mathrm{Ti}_{5} \mathrm{Si}_{3}$ and $\mathrm{Ti}_{5} \mathrm{Si}_{4}$ ) thermodynamic data derived by Vahlas et all. [22] was introduced in the original data base from the ChemSage package.

This package was used to derive the range of controllable experimental variables (temperature, total pressure and gas precursor ratios) producing the required condensed phases at equilibrium. This information was condensed in the usual CVD phase diagrams, where "windows of operation" leading to the deposition of the $\mathrm{TiN}$ and/or $\mathrm{Si}_{3} \mathrm{~N}_{4}$ phases are defined as a function of the above mentioned experimental parameters.

The efficiency of conversion of the parental $\mathrm{SiH}_{4}$ and $\mathrm{TiCl}_{4}$ molecules into $\mathrm{Si}_{3} \mathrm{~N}_{4}$ and TiN were plotted against pressure and temperature. The dependence of the partial pressures of the more relevant gaseous species participating in the heterogeneous equilibrium on processing temperature and pressure have also been derived.

Table I - Chemical species considered in the thermodynamic calculations

Gas Phase

$\begin{array}{llll}\mathrm{Cl} & \mathrm{NH}_{3} & \mathrm{SiH} & \mathrm{Si}_{3} \\ \mathrm{Cl}_{2} & \mathrm{~N}_{2} & \mathrm{SiHCl}_{3} & \mathrm{Ti} \\ \mathbf{H} & \mathrm{N}_{2} \mathrm{H}_{4} & \mathrm{SiH}_{2} & \mathrm{TiCl} \\ \mathbf{H C l} & \mathrm{Si} & \mathrm{SiH}_{2} \mathrm{Cl}_{2} & \mathrm{TiCl}_{2} \\ \mathrm{H}_{2} & \mathrm{SiCl} & \mathrm{SiH}_{3} & \mathrm{TiCl}_{3} \\ \mathbf{N} & \mathrm{SiCl}_{2} & \mathrm{SiH}_{3} \mathrm{Cl} & \mathrm{TiCl}_{4} \\ \mathbf{N H} & \mathrm{SiCl}_{3} & \mathrm{SiH}_{4} & \mathrm{Ti}_{2} \mathrm{Cl}_{6} \\ \mathrm{NH}_{2} & \mathrm{SiCl}_{4} & \mathrm{Si}_{2} & -\end{array}$

Condensed Phases

$\begin{array}{ll}\mathrm{NH}_{4} \mathrm{Cl} & \mathrm{TiCl}_{4} \\ \mathrm{Si} & \mathrm{TiH}_{2} \\ \mathrm{SiCl} & \\ \mathrm{Si}_{4} \mathrm{H}_{6} & \mathrm{TiN} \\ \mathrm{Si}_{3} \mathrm{~N}_{4} & \mathrm{TiSi} \\ \mathrm{Ti} & \mathrm{TiSi}_{2} \\ \mathrm{TiCl}_{2} & \mathrm{Ti}_{3} \mathrm{Si} \\ \mathrm{Ti}_{5} \mathrm{Si}_{3} \\ \mathrm{TiCl}_{3} & \mathrm{Ti}_{5} \mathrm{Si}_{4}\end{array}$

Fig. 4 shows the CVD phase diagram calculated for the $\mathrm{TiCl}_{4} / \mathrm{SiH}_{4} / \mathrm{N}_{2} / \mathrm{H}_{2}$ gas mixture as a function of temperature and $\mathrm{TiCl}_{4}$ precursor ratio, $\mathrm{TiCl}_{4} /\left(\mathrm{SiH}_{4}+\mathrm{TiCl}_{4}\right)$, at a pressure of 1 Torr and a $\mathrm{N}_{2}$ molar fraction, $\mathrm{N}_{2} /\left(\mathrm{SiH}_{4}+\mathrm{TiCl}_{4}\right)=10$.

As indicated in this diagram, $\mathrm{Si}_{3} \mathrm{~N}_{4}$ is expected to be co-deposited with TiN for deposition temperatures below $1200^{\circ} \mathrm{K}$, provided the $\mathrm{TiCl}_{4}$ precursor ratio is kept below 0.7 . For higher processing temperatures, the production of $\mathrm{TiN}$ as a single phase is predicted irrespective of the $\mathrm{TiCl}_{4}$ precursor ratio used, except for the high $\mathrm{TiCl}_{4}$ precursor ratio and relatively high deposition temperature region shown in this diagram, where no solid phases are likely to be formed.

Further calculations have shown that increasing the total pressure the $\mathrm{TiN}-\mathrm{Si}_{3} \mathrm{~N}_{4}$ co-deposition region is 
extended towards higher deposition temperatures and $\mathrm{TiCl}_{4}$ precursor ratios. The non-deposition region is also gradually reduced for increased pressures, completely disappearing at atmospheric pressure.

The influence of $\mathrm{H}_{2}$ partial pressure is shown in the parameterisation of this CVD phase diagram for different $\mathrm{H}_{2}$ dilution rates, $\mathrm{H}_{2} /\left(\mathrm{SiH}_{4}+\mathrm{TiCl}_{4}\right)$, also shown in Fig.4.

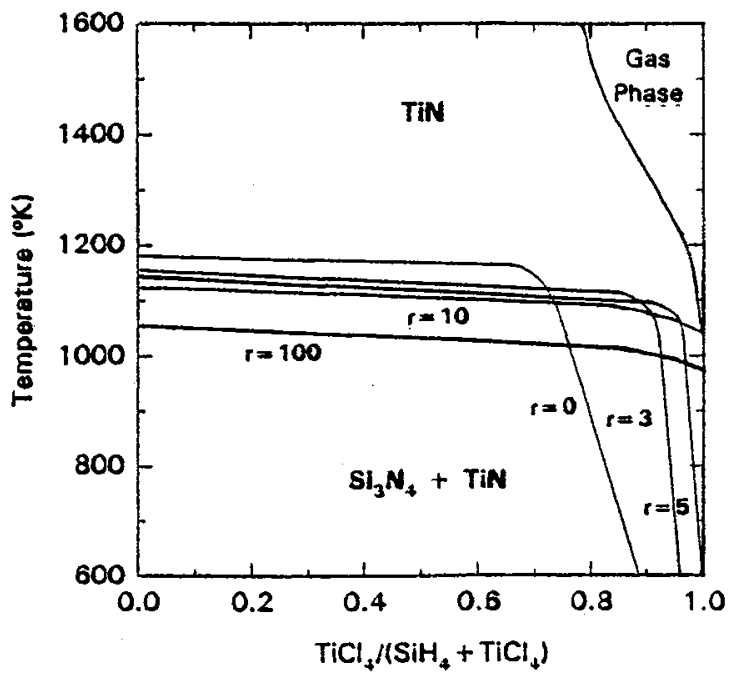

Figure 4: $\quad$ CVD phase diagram for the $\mathrm{TiCl}_{4} / \mathrm{SiH}_{4} / \mathrm{N}_{2} / \mathrm{H}_{2}$ gas mixture calculated for different $\mathrm{H}_{2}$ dilution rates, $\mathrm{r}=\mathrm{H}_{2} /\left(\mathrm{SiH}_{4}+\mathrm{TiCl}_{4}\right)$, at a pressure of 1 Torr and a $\mathrm{N}_{2}$ molar fraction, $\mathrm{N}_{2} /\left(\mathrm{SiH}_{4}+\mathrm{TiCl}_{4}\right)=10$.

Increased $\mathrm{H}_{2}$ dilution favours the dissociation of $\mathrm{TiCl}_{4}$, extending the stability of the TiN phase to lower temperatures, and allowing the co-deposition of $\mathrm{TiN}$ and $\mathrm{Si}_{3} \mathrm{~N}_{4}$ for higher $\mathrm{TiCl}_{4}$ molar ratios.

This last effect is better put in evidence in Fig. $5 \mathrm{a}$ ) and b), representing the conversion efficiencies of $\mathrm{TiCl}_{4}$ and $\mathrm{SiH}_{4}$ into $\mathrm{TiN}$ and $\mathrm{Si}_{3} \mathrm{~N}_{4}$ respectively, as a function of the $\mathrm{TiCl}_{4}$ precursor ratio for a temperature of $1000^{\circ} \mathrm{K}$ and a pressure of 1 Torr.

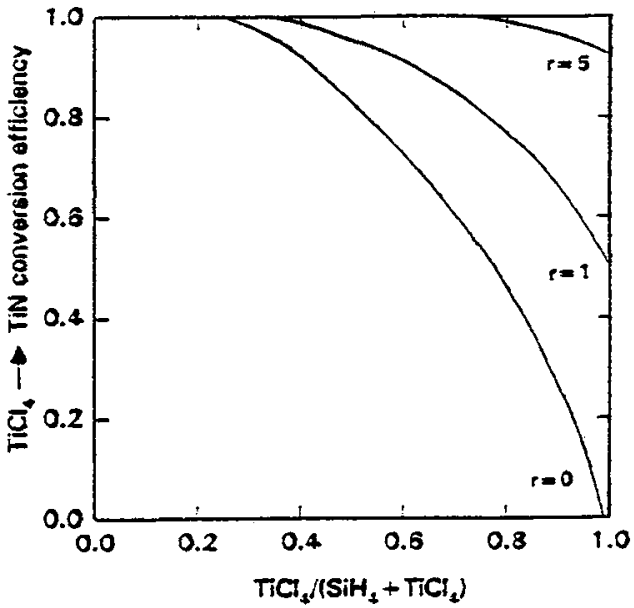

a)

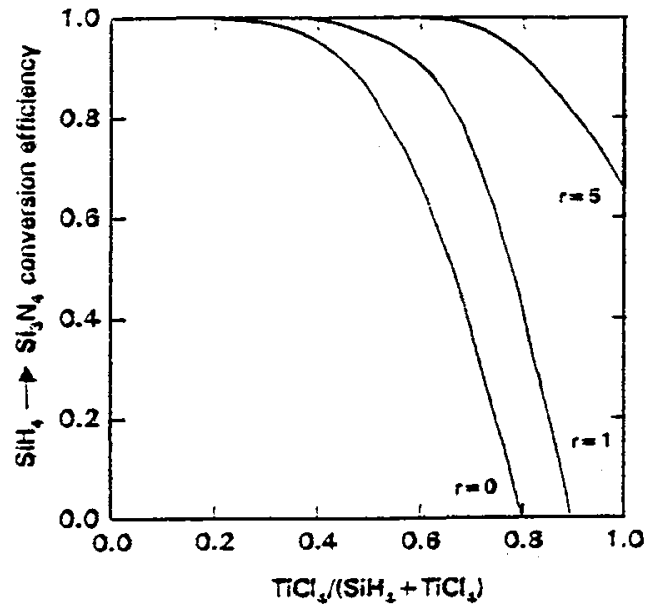

b)

Figure 5: Conversion efficiencies of $\mathrm{TiCl}_{4}$ a) and $\mathrm{SiH}_{4}$ b) molecules into $\mathrm{TiN}$ and $\mathrm{Si}_{3} \mathrm{~N}_{4}$ respectively, calculated for different $\mathrm{H}_{2}$ dilution rates, $\mathrm{r}=\mathrm{H}_{2} /\left(\mathrm{SiH}_{4}+\mathrm{TiCl}_{4}\right)$, at a temperature of $1000^{\circ} \mathrm{K}$ and a pressure of 1 Torr. 
Both yields of formation and notably the $\mathrm{Si}_{3} \mathrm{~N}_{4}$ yield are strongly enhanced by the presence of $\mathrm{H}_{2}$, attaining values close to unity for $\mathrm{H}_{2}$ dilution rates higher than 5 , almost independently of the $\mathrm{TiCl}_{4}$ precursor ratio considered. The beneficial effect of $\mathrm{H}_{2}$ dilution in the formation of $\mathrm{Si}_{3} \mathrm{~N}_{4}$ was not foreseen in the simplified equilibrium described by reaction 2 .

Contrary to the influence of increased $\mathrm{H}_{2}$ dilutions, further increase in the $\mathrm{N}_{2}$ molar fraction above the stoichiometric ratios does not change significantly the corresponding CVD phase diagram. An almost negligible extension of $100^{\circ} \mathrm{K}$ in the TiN stability zone towards lower deposition temperatures was observed increasing stepwise the $\mathrm{N}_{2}$ molar fractions from 5 to 1000 , irrespective of the total pressure. The next step towards the optimization of the deposition process of $\mathrm{TiN}-\mathrm{Si}_{3} \mathrm{~N}_{4}$ composites is to analyze the influence of processing temperature and pressure on the yields of formation of TiN and $\mathrm{Si}_{3} \mathrm{~N}_{4}$ for a given precursor ratio leading to the co-deposition of these phases.

The dependence of $\mathrm{TiN}$ and $\mathrm{Si}_{3} \mathrm{~N}_{4}$ yields of formation on processing temperature and pressure are shown in Fig. 6 a) and b), respectively, for a 0.1:0.1:1:0.5 TiCl $/ 4 \mathrm{SiH}_{2} / \mathrm{N}_{2} / \mathrm{H}_{2}$ gaseous mixture.

Co-deposition of $\mathrm{TiN}$ and $\mathrm{Si}_{3} \mathrm{~N}_{4}$ with conversion efficiencies for both gaseous precursors $\left(\mathrm{TiCl}_{4}\right.$ and $\mathrm{SiH}_{4}$, respectively) near $100 \%$ is achieved between 1000 and $1100^{\circ} \mathrm{K}$. For higher temperatures the yield of formation of $\mathrm{Si}_{3} \mathrm{~N}_{4}$ sharply drops to zero, whereas the efficiency of conversion of TiN stays more or less constant (region of TiN single phase deposition).

As far as the dependence of TiN and $\mathrm{Si}_{3} \mathrm{~N}_{4}$ yields of formation on pressure, a compromise seems to exist between the continuous small drop of the conversion efficiency of $\mathrm{TiN}$ with pressure and the maximum of the corresponding $\mathrm{Si}_{3} \mathrm{~N}_{4}$ factor around 1 Torr. Provided the pressure is kept between 1 and 10 Torr yields of formation in excess of 0.97 are predicted for both phases.

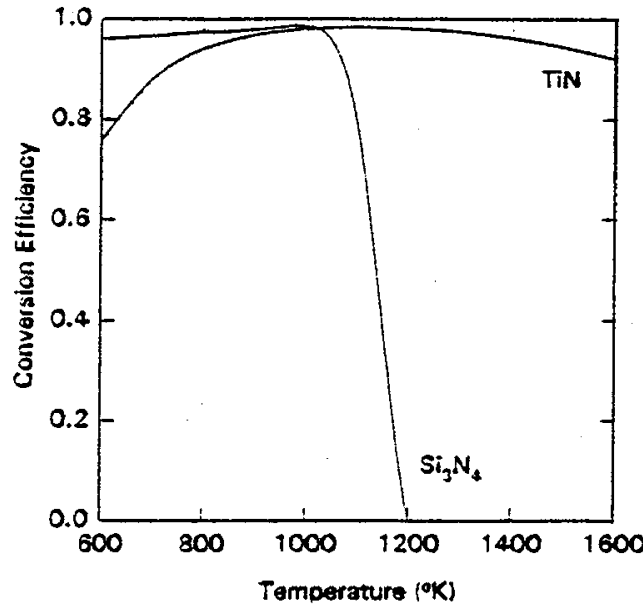

a)

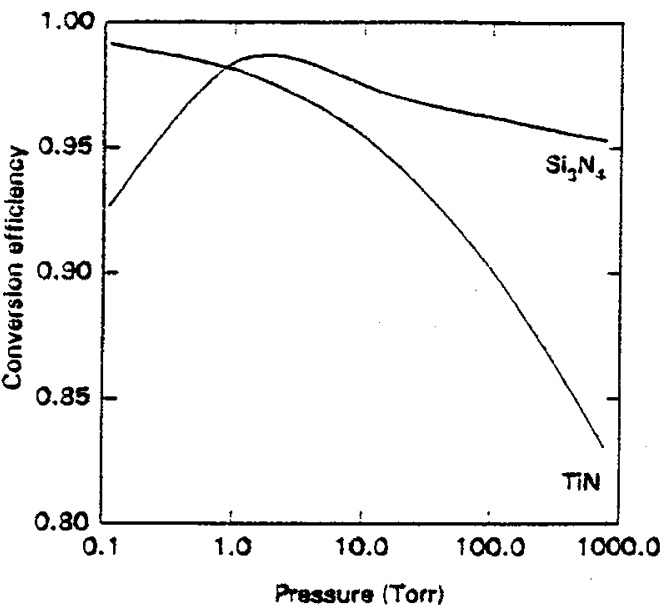

b)

Figure 6 : Dependence of $\mathrm{TiN}$ and $\mathrm{Si}_{3} \mathrm{~N}_{4}$ yields of formation on processing temperature a) and pressure b) calculated for a $0.1: 0.1: 1: 0.5 \mathrm{TiCl}_{4} / \mathrm{SiH}_{4} / \mathrm{N}_{2} / \mathrm{H}_{2}$ gaseous mixture.

The dependence of the corresponding equilibrium partial pressures of the most significant gaseous species on deposition temperature and pressure are shown in Fig. 7 a) and b) for a pressure of 1 Torr and a temperature of $1000^{\circ} \mathrm{K}$, respectively.

The most significant gas species are the $\mathrm{N}_{2}$ and $\mathrm{H}_{2}$ gaseous precursors and $\mathrm{HCl}$.

The molar fraction of $\mathrm{H}_{2}$ is always higher than the corresponding reactant input. In this respect, it is also interesting to mention that the deposition of TiN is predicted even in the absence of $\mathrm{H}_{2}$ as a reactant, as illustrated in Fig. 4. This is a result the initial reaction of silane decomposition [23],

$$
\mathrm{SiH}_{4}=\mathrm{SiH}_{2}+\mathrm{H}_{2}
$$


which leads to the production of silylene molecules and hydrogen.

The relatively high concentration of $\mathrm{HCl}$ is also a result of excess $\mathrm{H}_{2}$ reacting with $\mathrm{TiCl}_{\mathrm{x}}$ species. The gas phase concentration of $\mathrm{SiH}_{2}$ increases abruptly upon the transition from $\mathrm{TiN}-\mathrm{Si}_{3} \mathrm{~N}_{4}$ co-deposition to TiN single phase deposition. A strong reduction on silylene molecules concentration is also observed for increasing pressures.

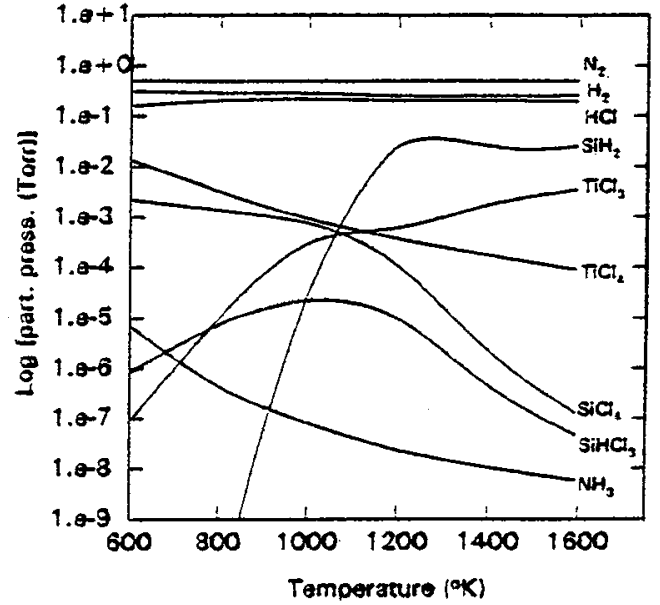

a)

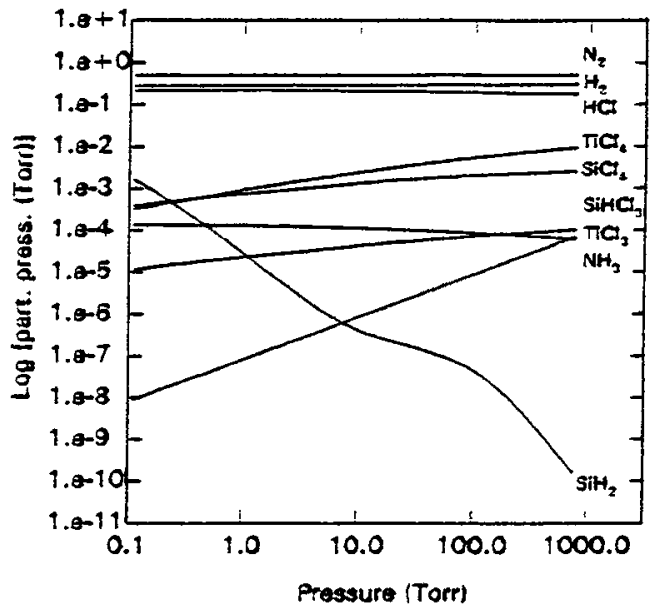

b)

Figure 7: Dependence of the equilibrium partial pressures of the most significant gaseous species on deposition temperature a) and pressure b) calculated for a 0.1:0.1:1:0.5 TiCl $/ 4 \mathrm{SiH}_{4} / \mathrm{N}_{2} / \mathrm{H}_{2}$ gaseous mixture at a pressure of 1 Torr and a temperature of $1000^{\circ} \mathrm{K}$, respectively.

The well known propensity of chlorine to combine with silicon forming various kinds of silicon chlorides and chlorosilanes is also evident from Fig. 7, the most important silicon-bearing gas species being $\mathrm{SiCl}_{4}$ and $\mathrm{SiHCl}_{3}$. These species seem to play an important role in the reactions leading to the formation of $\mathrm{SI}_{3} \mathrm{~N}_{4}$ once their concentration in the gas phase drops several orders of magnitude upon the transition (around $1100^{\circ} \mathrm{K}$ ) from $\mathrm{TiN}-\mathrm{Si}_{3} \mathrm{~N}_{4}$ co-deposition to TiN single phase deposition. The more relevant gas phase titanium-containing species are unreacted $\mathrm{TiCl}_{4}$ molecules and, specially at high temperatures, $\mathrm{TiCl}_{3}$. The above results suggest that $\mathrm{TiN}$ and $\mathrm{Si}_{3} \mathrm{~N}_{4}$ are deposited during separate reactions events explaining the absence of titanium silicides deposition.

\section{EXPERIMENTAL RESULTS}

The thermodynamic limitations of the CVD of $\mathrm{TiN}-\mathrm{Si}_{3} \mathrm{~N}_{4}$ composite coatings and the sensitivity of different reactive mixtures to modifications of relevant experimental parameters (e.g. temperature, pressure) were evaluated in the previous section by thermochemical equilibrium calculations. These calculations have shown that low pressure CVD of $\mathrm{TiN}-\mathrm{Si}_{3} \mathrm{~N}_{4}$ composite coatings in $\mathrm{TiCl}_{4} / \mathrm{SiH}_{4} / \mathrm{N}_{2} / \mathrm{H}_{2}$ gaseous mixtures can take place in a wide range of $\mathrm{TiCl}_{4} / \mathrm{SiH}_{4}$ gas ratios at temperatures below $1000^{\circ} \mathrm{K}$. Based on these results a preliminary set of test samples was deposited onto various substrates using an RF-DC triode cold wall PACVD system previously described [18]. The advantages of this RF-DC PACVD method over conventional thermal assisted CVD processing were reported elsewhere [18, 24]. The most important benefit of this processing methodology is to allow a more effective control of the energetic particle bombardment of the substrate promoting the formation of microstructures which increase the hardness of the coating material. Further, by using a plasma assisted process the deposition temperature can be lowered to $470^{\circ} \mathrm{C}$.

Following the predictions of the thermodynamic calculations, coatings were produced in $\mathrm{TiCl}_{4} / \mathrm{SiH}_{4} / \mathrm{N}_{2} / \mathrm{H}_{2}$ 
gas mixtures with over stoichiometric $\mathrm{H}_{2}$ dilution rates, $\mathrm{H}_{2} /\left(\mathrm{SiH}_{4}+\mathrm{TiCl}_{4}\right) \geq 50$, and moderate $\mathrm{N}_{2}$ dilutions, $\mathrm{N}_{2} /\left(\mathrm{SiH}_{4}+\mathrm{TiCl}_{4}\right) \leq 30$, to enable the co-deposition of $\mathrm{TiN}$ and $\mathrm{Si}_{3} \mathrm{~N}_{4}$ in a wide range of $\mathrm{TiCl}_{4}$ molar fractions. Low $\mathrm{TiCl}_{4}$ molar fractions, $\mathrm{TiCl}_{4} /\left(\mathrm{SiH}_{4}+\mathrm{TiCl}_{4}\right) \leq 0.3$ were used together with over stoichiometric $\mathrm{H}_{2}$ dilution rates to maximize in the range of pressures of interest (between 0.5 and 1.5 Torr) the conversion efficiencies of $\mathrm{TiCl}_{4}$ and $\mathrm{SiH}_{4}$ precursors into TiN and $\mathrm{Si}_{3} \mathrm{~N}_{4}$, respectively.

The crystallographic structure, composition and chemical bonding of the coatings were analyzed by $\mathrm{X}$-ray diffraction at grazing angle incidence, EPMA and IR spectroscopy measurements.

The crystallographic features of $\mathrm{Si}_{3} \mathrm{~N}_{4}$ were completely absent from the X-ray diffraction spectra of these coatings. The characteristic broad peaks of a not fully crystallised TiN phase were detected. The typical $\mathrm{SiN}$ vibrational modes of $\mathrm{Si}-\mathrm{N}$ bonds in $\mathrm{Si}_{3} \mathrm{~N}_{4}$ complexes were however present in the IR spectra of these coatings, confirming the presence of this phase in the coatings.

These results, suggesting that the coatings are TiN nanocrystallites embedded in an amorphous $\mathrm{Si}_{3} \mathrm{~N}_{4}$ phase, were confirmed by EPMA chemical bond investigations. The experimental data were fitted with mathematical functions describing the peak shapes of pure $\mathrm{Si}, \mathrm{SiO}_{2}$ and $\mathrm{Si}_{3} \mathrm{~N}_{4}$, as illustrated in Fig. 8 .

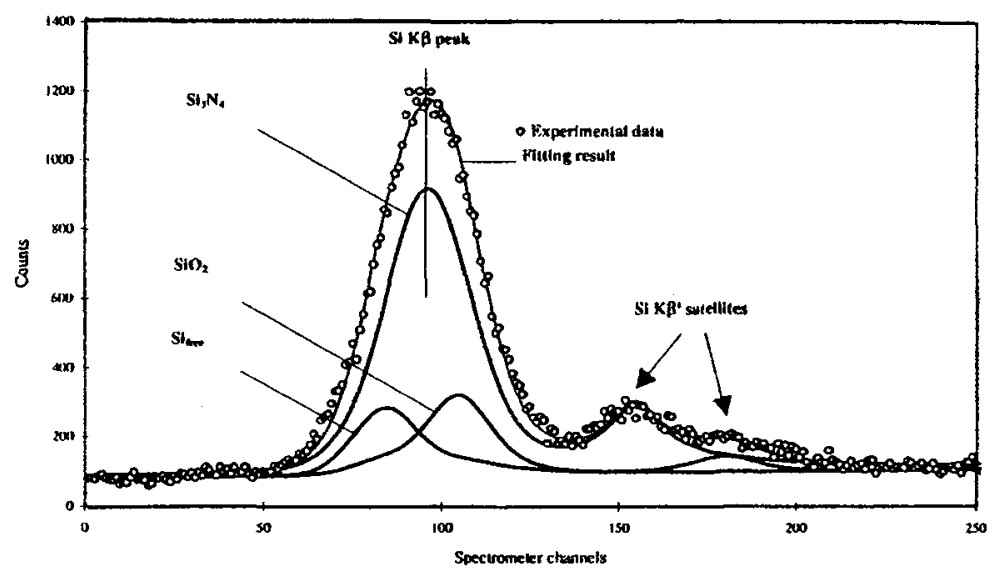

Figure 8 : EPMA spectrometer scan (PET crystal) around the $\operatorname{SiK} \beta$ position from a $\mathrm{TiN}-\mathrm{Si}_{3} \mathrm{~N}_{4}$ coating.

The concentration of the various phases was calculated in a semi quantitative fashion by introducing EPMA K-ratios for the single Si-compounds and combining them with the usual EPMA quantification [25]. Typical ratios between the $\mathrm{Si}_{3} \mathrm{~N}_{4}$ and the TiN phase are of the order of 2 . The great majority of the silicon atoms are bonded to nitrogen forming $\mathrm{Si}_{3} \mathrm{~N}_{4}$ complexes. A small amount of free silicon atoms (1-2 atom \%) is also present in these coatings. A reduced amount of oxidation of the $\mathrm{Si}_{3} \mathrm{~N}_{4}$ phase and to a lesser extent of the TiN phase was also detected.

The Knoop microhardness of the coatings were of the same order of similar TiN coatings prepared in the same deposition system. The higher Si content of the present coatings (typically 30 atom \%) when compared with previous work $[19,20]$, where microhardness values in excess of TiN were attained for $10-15 \%$ of $\mathrm{Si}$ atoms explains their relatively low hardness values.

\section{CONCLUSIONS}

The development of $\mathrm{TiN}-\mathrm{Si}_{3} \mathrm{~N}_{4}$ composite coatings for high wear resistance applications was proposed as an alternative to diamond-like and cubic $\mathrm{BN}$ coatings.

An a-priori thermodynamic approach complemented by thermochemical equilibrium calculations was used to evaluate convenient precursors and processing parameters for the production of this novel coating material by Chemical Vapour Deposition (CVD) and Plasma Assisted CVD. These calculations were condensed in the form of CVD phase diagrams, where the "windows of operation" leading to the 
deposition of the TiN and/or $\mathrm{Si}_{3} \mathrm{~N}_{4}$ phases were defined as a function of relevant experimental parameters (temperature, total pressure and gaseous precursor ratios). The dependence of the production yields of $\mathrm{TiN}$ and $\mathrm{Si}_{3} \mathrm{~N}_{4}$ phases on temperature and pressure were also derived.

These results have shown that the deposition of $\mathrm{TiN}-\mathrm{Si}_{3} \mathrm{~N}_{4}$ composite coatings is favoured by using $\mathrm{TiCl}_{4} / \mathrm{SiH}_{4} / \mathrm{N}_{2} / \mathrm{H}_{2}$ instead of $\mathrm{TiCl}_{4} / \mathrm{SiCl}_{4} / \mathrm{N}_{2} / \mathrm{H}_{2}$ gaseous mixtures. TiN-Si $\mathrm{N}_{4}$ nano composite coatings can be produced at temperatures below $1000^{\circ} \mathrm{K}$ for a wide range of $\mathrm{TiCl}_{4} / \mathrm{SiH}_{4}$ gas ratios.

The multiphase nature of preliminary test samples deposited by PACVD was confirmed by X-ray diffraction at grazing angle incidence, IR spectroscopy and EPMA analysis. The films were made up of TiN nanocrystallites embedded in an amorphous $\mathrm{Si}_{3} \mathrm{~N}_{4}$ matrix with small amounts of free $\mathrm{Si}$, as predicted by previous $\mathbf{T i}-\mathrm{Si}-\mathrm{N}$ phase diagrams calculations.

Further work is in progress to apply the results of the thermochemical equilibrium calculations in the optimization of the $\mathrm{TiN}-\mathrm{Si}_{3} \mathrm{~N}_{4}$ composite coatings deposition process aiming the attainment of higher hardness values.

\section{References}

[1] H. Holleck, Surf. Eng. 7 (1991) 137.

[2] J. E. Sundgren and H. T. G. Hentzell, J. Vac. Sci. Technol. A4 (1986) 2259.

[3] P. Rodhammer, Proc. SURFTEC, (Berlim 1989) pp. 115.

[4] R. C. Cammarata, Thin Solid Films 240 (1994) 82.

[5] R. Beyers, R. Sinclair and M. E. Thomas, J. Vac. Sci. Technol. B2 (1984) 781.

[6] K. T. Rie, St. Einsenberg and A. Gebauer, Proc. $1^{\text {st }}$ Int. Conf. on Plasma Surface Engineering, (Garmish-Partenkirchen 1988) pp. 155.

[7] M. R. Hilton, L. R. Narasimban, S. Nakamura, M. Salmeron and G. A. Somorjai, Thin Solid Films 139 (1986) 247.

[8] S. J. Bull, P. R. Chalker, C. F. Ayres and D. S. Rickerby, Mat Sci. Eng. A139 (1991) 71.

[9] W. Posadowsky, Thin Solid Films 162 (1988) 111.

[10] Zh. A. Mrochek, B. A. Eizner, I. A. Ivanov and T. S. Levchenko, Eleckrommaya Obrabotka Materialov 5 (1989) 14 (English translation).

[11] T. Hiray and S. Hayashi, Comm. of the Am. Ceram. Soc. (1981) C-88.

[12] T. Hirai and S. Hayashi, J. Mat. Sci. 17 (1982) 1320.

[13] S. Hayashi, T. Hirai, K. Hiraga and M. Hirabayashi, J. Mat. Sci. 17 (1982) 3336.

[14] T. Hirai and S. Hayashi, J. Mat. Sci. 18 (1983) 2401.

[15] L. Shizhi, S. Yulong and P. Hongrui, Plasma Chem. Plasma Process. 12 (1992) 287.

[16] I. Endler, E. Wolf, A. Beger and V. Richter, Proc. $4^{\text {th }}$ Int. Symp. on Trends and New Applications in Thin Films (DGM Informationgesellchaft 1994) pp. 250.

[17] S. R. Kurtz and R. G. Gordon, Thin Solid Films 140 (1986) 277.

[18] J. H. van Breda, A. G. Dias, W. G. Haije and D. C Schram, Proc. $4^{\text {th }}$ Int. Conf. on Plasma Surface Engineering, (Garmish-Partenkirchen (1994), to be published.

[19] M. E. Sjostrand, Proc. 7th Int. Conf. on CVD, (Electrochemical Society 1979) pp. 452.

[20] Y. Saeki, R. Matsuzaki, A. Yajima and M. Akyiama, Bull. Chem. Soc. Jpn. 55 (1982) 3193.

[21] G. Eriksson, Chem. Scr. 8 (1975) 100.

[22] C. Vahlas, P. Y. Chevalier and E. Blanquet, Calphad, 13 (1989) 273.

[23] M. Tao, Thin Solid Films 223 (1993) 201.

[24] J. H. van Breda,W. G. Waije and A. G. Dias, Proc. 12 ${ }^{\text {th }}$ ESCAMPIG, (Nordwijkerhout 1994) pp. 143.

[25] P. Moretto, private communication. 